\title{
adenows

\section{INTERFACE ENTRE UM MÉTODO DE TRATAMENTO PSÍQUICO E A CULTURA}

Pontifícia Universidade Católica de Minas Gerais - PUC Minas. Doutorando. Bolsista do CNPq.

Pontificia Universidade Católica de Minas Gerais - PUC Minas. Doutora. Bolsista de Produtividade em Pesquisa, CNPQ, nível PQ - 2, Membro da Escola Brasileira de Psicanálise (Brasil) e da Associação Mundial de Psicanálise (Paris, França).
Marcelo Soares Cotta Ilka Franco Ferrari

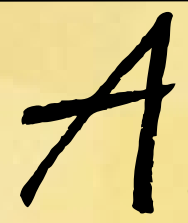

Resumo

desnaturalização do animal humano é algo constatado em diferentes campos de saber, a exemplo da Filosofia e Psicanálise. Isso remete diretamente ao fato de que para o humano não há a suposta harmonia entre natureza e cultura. O filósofo Diógenes, e sua escola dos Cínicos, em que a proposta era viver na virtude de acordo com a natureza, por exemplo, acreditava na possibilidade dessa harmonia e, consequentemente, do retorno da vivência da sexualidade ao modo natural, como os demais animais. Desde Freud, e com suas contribuições, tem-se a clareza da impossibilidade de ignorar a realidade social no horizonte de sua época, pois a realidade social é algo construído, portanto modificável e variável. A Psicanálise permite leitura de fatos sociais, de sintomas sociais, indicadores daquilo que não vai bem em determinada ordem social estabelecida, do malestar que lhe é inerente. Há analistas em instituições, na cidade, tal como Freud desejava. Tal expansão fez com que os estudiosos da Psicanálise, a exemplo de Marie-Hélène Brousse, reconhecida pelo trabalho prático e teórico que desenvolve, buscassem sistematizar um pouco mais as coordenadas que orientariam tais ações. Essa autora isolou três pontos de ancoragem que não podem ser perdidos de vista, quando se trata de praticar psicanálise: operar segundo o referencial do SsS, ou seja, sujeito suposto saber (a transferência); sustentar o S barrado (\$), sujeito do inconsciente enquanto saber textual e não simplesmente um referencial; e manutenção, no horizonte, da dimensão do A barrado ( $\mathrm{A})$, do Outro que não existe.

Palavras-chave: Freud. Cultura. Método de tratamento. Psicanálise aplicada. 
A desnaturalização do animal humano é algo constatado em diferentes campos de saber, a exemplo da Filosofia e Psicanálise. Isso remete diretamente ao fato de que para o humano não há a suposta harmonia entre natureza e cultura. O filósofo Diógenes, e sua escola dos Cínicos, em que a proposta era viver na virtude de acordo com a natureza, por exemplo, acreditava na possibilidade dessa harmonia e, consequentemente, do retorno da vivência da sexualidade ao modo natural, como os demais animais. $\mathrm{O}$ método de Diógenes pregava que o homem deveria manter-se em harmonia com o natural assim "o homem satisfaria uma necessidade supostamente orgânica, no campo da sexualidade, sem entrar em relação com outros seres humanos" (MILLER, 1997, p. 288). Assim sendo, se masturbaria publicamente em defesa do instinto sexual, mas, desde Freud, os estudiosos já não podem ignorar que fatos que poderiam ser da ordem do natural, na humanidade, sofrem a ação da cultura, por exemplo, ter e ser filho, pai, mãe, pertencer a determinado espaço coletivo.

Ao observar os animais, pode-se constatar que não há nenhum inconveniente em ter relações sexuais com os pais, com os irmãos e irmãs e até com os avós. Na ordem natural, a satisfação do instinto sexual, das relações sexuais, se dá de forma diferente do que na civilização. Nas relações humanas, as exigências de ordem social substituíriam a natureza do instinto animal e a transformaram em pulsão. Com esse tipo de pensamento "fundado na história da cultura, Freud foi lido como um liberador da sexualidade humana recalcada, e a psicanálise, tomando o partido do instinto sexual, anunciava uma nova época: a da liberação do desejo" (MILLER, 1997, p. 288).

Wilhelm Reich faz uma interpretação de Freud ao criar o movimento sex pol (sexualidade política), em que reivindica a liberação do sexo contra o social vigente. Para Reich, caso a sexualidade seja submetida ao domínio político, por parte do Estado, da burguesia, pode-se concluir que haveria coação e o desejo ficaria refém do social. Sua ideia é que somos prisioneiros do cárcere social, político, sem ter conhecimento do fato, como se o lugar que o sexo deveria estar é no nível do natural.

Freud, entretanto, não fala em coação, mas em recalcamento, que difere de repressão social (MILLER, 1997). A ideia de recalque supõe haver censura, uma barra que impediria $o$ material inconsciente de aparecer ao nível do consciente, mas o recalcado sempre retorna e se manifesta de outras maneiras, 
como lapsos, atos falhos, sonhos, chistes, sintomas, mal-estar. Freud (1923, p. 305) esclarece que "acreditar que a psicanálise busca a cura dos distúrbios neuróticos dando rédea livre à sexualidade é uma grave má interpretação". Durante uma análise existe a "tomada de consciência dos desejos sexuais reprimidos [recalcados]" e, dessa forma, é possível "obter sobre eles um domínio" que antes era impedido pelo recalque.

Em seu texto, "Mal-Estar na civilização", FREUD (1929, p. 105) afirma que "[...] o que chamamos de nossa civilização é em grande parte responsável por nossa desgraça, e que seríamos muito mais felizes se a abandonássemos e retornássemos às condições primitivas". Para Freud (1929, p. 137), "o homem primitivo se achava em situação melhor, sem conhecer restrições de instinto. [...] O homem civilizado trocou uma parcela de suas possibilidades de felicidade por uma parcela de segurança.". Assim, o homem seria mais feliz sem a civilização, porém não consegue viver fora dela, devido aos benefícios que esta the proporciona. O processo civilizatório exige que a felicidade seja colocada em segundo plano, com isso implicando contínuo mal-estar para os humanos. Freud localizou, portanto, o malestar como oriundo da renúncia pulsional infringida ao sujeito pelo esforço civilizatório. Esse esforço transformou a natureza do homem, sujeitando-o à cultura.

Quando se diz que o homem é um animal político, ou um animal que fala, é dizer que, na humanidade, a natureza foi substituída pela cultura, e, segundo o psicanalista Jacques Alain Miller (1997, p. 288), há aí "a substituição ou a dominação da cultura sobre a natureza". Ao se tratar da desnaturalização do animal humano, é crucial versar sobre a diferença entre instinto (animal) e pulsão (ser humano). Os instintos são padrões de comportamentos que dirigem os animais para determinados fins particulares, um objeto específico. A pulsão insere a possibilidade de substituição do objeto de satisfação. A pulsão é o instinto que se desnaturaliza, que se desvia de suas fontes e de seus objetos específicos, originais. A pulsão de fato se apoia no instinto, mas não se reduz a ele. Na pulsão há uma ausência de objeto específico e uma impossibilidade de satisfação plena, mas ela acaba por operar uma relativilização no assujeitamento do homem com as chamadas necessidades naturais.

Freud explorou o que se passava na cultura não para dar uma visão geral da cidade ou do Estado, mas para entender o que se passava na experiência analítica. Sua análise dos problemas culturais é inscrita na psicanálise como ilustração de suas teorias 


\section{adenows \\ ESPUC \\ BELO HORIZONTE - N. 28 - 2016}

marcelo Sonres Cotta e Ilka Franco Ferrari

e forma de compreender as diversas esferas em que circula o fazer humano.

A psicanálise aborda questões que vão além de um método de tratamento clínico, e a forma de seu aparecimento em países como França e Alemanha demonstra esse fato.

\footnotetext{
$\mathrm{Na}$ França o interesse pela psicanálise começou entre os homens de letra. A fim de compreender isso, deve-se ter em mente que, desde a época em que foi escrita $A$ "Interpretação de Sonhos" a psicanálise deixou de ser um assunto puramente médico. Entre seu surgimento na Alemanha e na França está a história de suas numerosas aplicações a departamentos de literatura e estética, à história das religiões e à pré-história, à mitologia, ao folclore, à educação, e assim por diante (FREUD, 1925, p. 78).
}

Quando trata dos objetos da cultura, Freud fala de sublimação e não pensa num esquema do sexo como recalcado pelo social. A sublimação é um processo em que a libido se afasta do objeto sexual e ocorre uma substituição para outro objeto ou tipo de satisfação. Nesse curso, a sublimação opera a possibilidade de atingir certo grau de satisfação sexual, a despeito da defesa. Nesse processo, é possível se satisfazer com os objetos de substituição e desviar a energia libidinal de suas metas originais (incestuosas), investindo-a em realizações culturais. Através desse mecanismo, é possível conciliar parcialmente as exigências sexuais com as da cultura. $\mathrm{Na}$ obra de Freud, a noção de sublimação se fez presente em vários textos, desde a correspondência com Fliess, ainda no século XIX, até o texto "Esboço de Psicanálise" (FREUD, 1938). Para ele, a sublimação é um mecanismo de defesa positivo para a sociedade, contribuindo para o bem social. Pode-se dizer que grande parte dos feitos e dos objetos existentes na história humana foi alcançada graças à sublimação. Grandes artistas, cientistas que obtiveram grandes realizações e foram considerados acima da média, eram sujeitos cujas pulsões não se manifestaram tal como eram, em vez disso, sublimaram e transformaram essas forças em realizações sociais de grande valor, como as realizações artísticas. Pode-se dizer que as realizações artísticas não são uma simples projeção do artista, mas uma tentativa de solução de seus conflitos psíquicos. É possível analisar suas obras de arte apoiando-se na teoria psicanalítica. A sublimação torna possível a mudança nos objetivos da pulsão, que abandonaria seus objetos originais de natureza sexual, para se conectar a outras metas, as quais são socialmente apreciadas, como a arte, 
o esporte, a ciência, a religião, etc.

A pulsão sexual tem o sexo por objetivo, mas pode satisfazerse com outros objetivos como, por exemplo, a cultura. Nessa substituição, os objetivos de cultura substituem os puramente sexuais. Segundo Miller,

Temos que supor que fazer ou escutar filosofia, fazer ou ver esculturas, traz um gozo profundo. $\mathrm{O}$ conceito de sexualidade em Freud é novo porque tem como componente essencial que a sexualidade pode satisfazerse com palavras, com o belo, com os valores mais altos da cultura (MILLER, 1997, p. 289).

O ser humano é um animal sexual e com algo definido: a vida. Aos acontecimentos da natureza, a civilização produz significados culturais, dessa forma um filho é um fato biológico, mas também recebe um nascimento cultural, um pai, uma mãe, enfim uma identidade. Sendo assim, pode-se dizer que a cultura metaforiza a natureza. Pode-se pensar que o sujeito, não coagido, falaria de filosofia, de números divinos, de Deus, da beleza, da arte, mas isso não acontece. Segundo Miller:

O sujeito fala de coisas menos dignas. Não fala das ideias de Platão, ou dos objetos a propósito dos quais Sócrates respondeu a Pitágoras, a Parmênides. É uma constatação cruel para a espécie humana que o sujeito goza de sua palavra com grande custo, e como passagem obrigatória fala da família, do pai, da mãe, dos irmãos, dos avós etc. (MILLER, 1997, p. 290).

Freud (1923, p. 305) escreve que a psicanálise tem o objetivo de "chegar a uma visão harmônica de uma parte da realidade" e classifica como simplório o temor de que os bens da humanidade "perderão seu valor ou sua dignidade porque a psicanálise se encontra em posição de demonstrar sua origem em impulsos instintuais [pulsões] elementares e animais". Estava atento à interlocução da Psicanálise com outros saberes e, em seu texto "Novas Conferências Introdutórias sobre a Psicanálise", diz:

Disse-lhes que a psicanálise começou como um método de tratamento, mas não quis recomendá-lo ao interesse dos senhores como método de tratamento e sim por causa das verdades que ela contém, por causa das informações que nos dá a respeito daquilo que mais interessa aos seres humanos - sua própria natureza - e por causa das conexões que ela desvenda com as mais diversas atividades (FREUD 1932-1936, p. 191). 

sirvió de marco a las exposiciones y discusiones sobre el llamado psicoanálisis aplicado a los ámbitos de la literatura, las artes plásticas, la mitología y la historia. (RAMIREZ, 2007, p. 13).
13 La Sociedad Psicoanalítica de Viena

Através de suas formulações teóricas sobre a constituição do psiquismo humano, a psicanálise se coloca como uma fonte de subsídio para reflexões de e com outros discursos e, desde a "Sociedade Psicanalítica de Viena, serviu de marco para as exposições e discussões sobre a chamada psicanálise aplicada às áreas da literatura, artes plásticas, mitologia e história" (RAMIREZ, 2007, p. 13, tradução nossa) ${ }^{1}$. Nos anos de 1906 e 1907, muitas noites de Freud e seus colegas destinaram-se a discussões sobre psicanálise aplicada e sua interface com outros discursos, inclusive sobre o risco da interpretação psicanalítica excessiva a respeito de tudo (RAMIREZ, 2007).

Desde o começo da psicanálise aplicada instalouse a ambígua inquietação de dirigir-se a uma extraterritoriedade diferente do exercício da clínica individual e dos conceitos forjados em âmbito privado e, com o tempo, pensar os limites e a pertinência dessa extensão ao terreno público (RAMIREZ, 2007, p. 13, tradução nossa). ${ }^{2}$

2 Desde el comienzo del psicoanálisis aplicado, se instaló la inquietud ambigua de dirigirse a una extraterritorialidad distinta del ejercicio de la clínica individual y de los conceptos forjados en un ámbito privado y, al tiempo, pensar los límites y la pertinencia de esa extensión al terreno de lo público. (RAMIREZ, 2007, p. 13).
Dessa forma, desde Freud, e com suas contribuições, os profissionais dessa área têm a clareza da impossibilidade de ignorar a realidade social no horizonte de sua época, pois a realidade social é algo construído, portanto modificável e variável. A psicanálise permite leitura de fatos sociais, de sintomas sociais, indicadores daquilo que não vai bem em determinada ordem social estabelecida, do mal-estar que lhe é inerente. E, na atualidade de suas construções, frescor de seus ensinamentos, os profissionais orientados pela psicanálise estão aí, trabalhando em diferentes espaços, fazendo o que se conhece como psicanálise aplicada, psicanálise em extensão para Freud, e os cuidadosos zelam para que esse trabalho possa acontecer sem ser distorcido ou se dissolver em meio a outros discursos.

Sigmund Freud já ensinava, para que o trabalho orientado pela psicanálise possa acontecer, sem que seu discurso seja distorcido ou se dissolva nos demais discursos, é necessário o rigor na formação do analista, sempre baseada no tripé reafirmado pelo psicanalista francês Jacques Lacan (1998): formação teórica, análise pessoal, supervisão clínica. Com sua expansão, estudiosos da psicanálise, a exemplo de Marie-Hélène Brousse, reconhecida pelo trabalho prático e teórico que desenvolve, buscaram sistematizar um pouco mais as coordenadas que orientariam tais ações. Essa autora isolou três pontos de ancoragem que não podem ser perdidos de vista, quando se trata de praticar psicanálise: operar segundo o referencial do $\mathrm{SsS}$, ou seja, sujeito suposto saber (a transferência); sustentar o $\mathrm{S}$ barrado (\$), sujeito do inconsciente enquanto saber textual e não simplesmente um 


\section{ESPUC

referencial; e manutenção, no horizonte, da dimensão do A barrado $(\AA)$, do Outro que não existe. Brousse acrescenta que

a psicanálise aplicada é um móbil maior para o futuro da psicanálise, tanto como disciplina quanto como solução ética nova, introduzida na civilização por meio dessa experiência original que é um tratamento psicanalítico. BROUSSE, 2007, p.22)

E trabalhadores transferidos com a psicanálise estão por aí, nas instituições públicas de saúde, em universidades, em hospitais, nas comunidades terapêuticas, em clínicas de tratamento da toxicomania, dando o testemunho vivo da atualidade das ideias freudianas em nossa civilização.

\section{INTERFACE BETWEEN A PSYCHIC TREATMENT METHOD AND CULTURE}

\section{ABSTRACT}

The human animal denaturalization is something found in different fields of knowledge, such as philosophy and psychoanalysis. This refers directly to the fact that for humans there is not the supposed harmony between nature and culture. The philosopher Diogenes and his school of Cynics, which had a proposal to live in virtue according to nature, for example, believed in the possibility of such harmony and consequently the return of the experience of sexuality to the natural way, as the other animals. Since Freud and his contributions, it is evident the impossibility of ignoring the social reality on the horizon of one's time, because social reality is something constructed, therefore changeable and variable. Psychoanalysis allows the interpretation of social facts, social symptoms, indicators of what is not going well in certain established social order, the malaise that is inherent. There are analysts in institutions in the city, as Freud wanted. Such expansion caused scholars of psychoanalysis, like MarieHélène Brousse, recognized by the practical and theoretical work that she develops, to seek to systematize a little more the coordinates that would guide such actions. This author isolated three anchor points that cannot be missed when it comes to practicing psychoanalysis: to operate under the framework of the SsS, i.e., subject supposed to know (the transference); support the barred S (\$), subject of the unconscious as textual knowledge and not just a reference; and maintenance on the horizon of the size of the barred $A$ (A), the Other that does not exist.

Keywords: Freud. Culture. Treatment method. Applied Psychoanalysis. 


\section{REFERÊNCIAS}

BROUSSE, Marie Helene. Três pontos de ancoragem. In: Associação do Campo Freudiano (reunião). Pertinências da Psicanálise Aplicada: trabalhos da Escola da Causa Freudiana. Rio de Janeiro: Forense Universitária, 2007. p. 22-26.

FREUD, Sigmund. Dois Verbetes de Enciclopédia. In: FREUD, Sigmund.Edição Standard Brasileira das Obras Psicológicas Completas de Sigmund Freud. Rio de janeiro: Imago, 19231969. (24 volumes) v. XVIII.

FREUD, Sigmund. Um Estudo Autobiográfico. In: FREUD, Sigmund.Edição Standard Brasileira das Obras Psicológicas Completas de Sigmund Freud. Rio de Janeiro: Imago, 19251969. (24 volumes) v. XX.

FREUD, Sigmund. O mal-estar na civilização. In: FREUD, Sigmund.Edição Standard Brasileira das Obras Psicológicas Completas de Sigmund Freud. Rio de janeiro: Imago, 19291969. (24 volumes) v. XXI.

FREUD, Sigmund. Novas conferências introdutórias sobre psicanálise. In: FREUD, Sigmund.Edição Standard Brasileira das Obras Psicológicas Completas de Sigmund Freud. Rio de Janeiro: Imago, 1932-1936-1969. (24 volumes) v. XXII.

FREUD, Sigmund. Esboço de Psicanálise (1938). In: FREUD, Sigmund.Edição Standard Brasileira das Obras Psicológicas Completas de Sigmund Freud. Rio de Janeiro: Imago, 1969. (24 volumes) v. XXIII.

LACAN, Jacques. Variantes do tratamento-padrão. In: Escritos. Rio de Janeiro: Jorge Zahar, 1998.

MILLER, Jacques-Alain. Lacan Elucidado. Rio de Janeiro, Jorge Zahar Editor, 1997.

RAMIREZ, Mário Elkin. Órdenes de hierro: ensayos de psicoanálisis aplicado a lo social. Medellin: La Carreta Editores, 2007.

REICH, Wilhelm. The sexual revolution: Toward a selfregulating character structure. New York: Farrar, Straus and Giroux, 1986.

Recebido em: 19/05/2015

Aceito em: 23/11/2015 